\title{
Sclerocarya birrea (Anacardiaceae) stem-bark extract corrects glycaemia in diabetic rats and acts on $\beta$-cells by enhancing glucose-stimulated insulin secretion
}

\author{
Ivonne Gisèle Makom Ndifossap ${ }^{1,2}$, Francesca Frigerio ${ }^{1}$, Marina Casimir ${ }^{1}$, Florence Ngueguim Tsofack ${ }^{2}$, \\ Etienne Dongo ${ }^{3}$, Pierre Kamtchouing ${ }^{2}$, Théophile Dimo ${ }^{2}$ and Pierre Maechler ${ }^{1}$ \\ ${ }^{1}$ Department of Cell Physiology and Metabolism, Faculty of Medicine, University of Geneva, 1 rue Michel-Servet, 1211 Geneva 4, Switzerland \\ Departments of ${ }^{2}$ Animal Biology and Physiology and ${ }^{3}$ Organic Chemistry, Faculty of Science, University of Yaoundé 1, PO Box 812, Yaoundé, Cameroon \\ (Correspondence should be addressed to P Maechler; Email: pierre.maechler@unige.ch)
}

\begin{abstract}
Sclerocarya birrea is a plant widely used as traditional medication for the treatment of diabetes in sub-Saharan regions. However, the mechanism of action is unknown and only hypoglycaemic effects of $S$. birrea extract (SBE) in diabetic rats have been reported to date. Here, we tested aqueous extracts of $S$. birrea on insulin-secreting INS-1E cells and isolated rat islets. Following $24 \mathrm{~h}$ of treatment at $5 \mu \mathrm{g} / \mathrm{ml}$, the extract markedly potentiated glucose-stimulated insulin secretion. Neither basal insulin release nor non-nutrient stimulation was affected. The potentiation of the secretory response at stimulatory glucose appeared after $12 \mathrm{~h}$ of treatment. No acute
\end{abstract}

effects were observed and, at the effective concentration, SBE was safe regarding cell integrity and differentiation. The mechanism of action of the SBE was related to glucose metabolism as both ATP generation and glucose oxidation were enhanced following the 24-h treatment. In streptozotocin-induced diabetic rats, SBE administration corrected glycaemia and restored plasma insulin levels after 2 weeks of treatment. These data show direct action of $S$. birrea on insulin-secreting cells and favour further delineation for use of the plant in the management of diabetes.

Journal of Endocrinology (2010) 205, 79-86

\section{Introduction}

Diabetes represents a growing health problem in Africa with rapidly increasing prevalence, in particular in subSaharan regions (Gill et al. 2009). Associated with economic constraints, it is crucial to identify effective and low-cost medications. Traditional remedies in Africa rely mostly on medicinal plants. Among them, Sclerocarya birrea ((A. Rich.) Hochst.) (Anacardiaceae) is one of the plant species widely used in Africa against various diseases, including diabetes (Dieye et al. 2008). In a cross-sectional survey conducted in Dakar, $43 \%$ of patients attending consultancy at the hospital declared using S. birrea (Dieye et al. 2008). This shows the wide use of the plant for the treatment of various diseases, although investigations on biological effects are lacking.

S. birrea stem-bark extracts have been shown to exert hypoglycaemic effects in animal models. In rats with streptozotocin-induced diabetes, acute administration of $S$. birrea stem-bark extract reduces blood glucose levels (Ojewole 2003, Dimo et al. 2007). Chronically, the efficacy of $S$. birrea stem-bark extract administered for 5 weeks was shown to be similar to metformin treatment with regards to lowering of glycaemia (Gondwe et al. 2008).
Despite these promising in vivo studies, cellular and molecular mechanisms responsible for hypoglycaemic effects of the plant have not been investigated. Blood glucose control depends on the normal regulation of insulin secretion from the pancreatic $\beta$-cells and the action of insulin on its target tissues. In the consensus model of glucose-stimulated insulin secretion, glucose phosphorylation initiates its metabolism (Iynedjian 2009), ultimately leading to plasma membrane depolarisation (Ashcroft 2006) and the ensuing cytosolic calcium rise inducing insulin exocytosis (Eliasson et al. 2008). Additional signals, generated by mitochondrial metabolism, amplify the calcium signal (Maechler et al. 2006). This process is referred to as metabolism-secretion coupling, since glucose oxidation promotes ATP generation necessary for the triggering of exocytosis signals. Elevation of plasma insulin was reported in stem-bark-treated diabetic rats (Dimo et al. 2007). Accordingly, it was of importance to investigate putative direct effects of $S$. birrea on insulin-secreting cells.

Regarding the in vivo hypoglycaemic effect of $S$. birrea stem-bark, chronic treatments have been reported only with organic extracts (Dimo et al. 2007, Gondwe et al. 2008), whereas aqueous extracts have been shown to be effective in acute conditions (Ojewole 2003). In the present study, we tested chronic effects of aqueous extracts of $S$. birrea stem-bark 
in vivo in diabetic rats and in vitro on insulin-secreting cells. Rats with nicotinamide-streptozotocin-induced diabetes were treated over a 14-day period, revealing efficiency of the treatment. For in vitro studies, we used both the well-differentiated insulinoma INS-1E cell line as well as the isolated rat islets. Aqueous extracts of $S$. birrea stem-bark were found to promote glucose metabolism and insulin secretion, demonstrating for the first time direct effects of $S$. birrea on insulin-secreting cells.

\section{Materials and Methods}

\section{Preparation of plant extract}

Fresh stem-bark of S. birrea ((A. Rich.) Hochst.) (Anacardiaceae) was collected in Garoua (North Province, Cameroon) and certified at the Department of Plant Biology and Physiology, University of Yaoundé I. A voucher specimen documenting the collection was deposited at the National Herbarium (Yaoundé) under the reference 7770 HNC.

One kilogram of air-dried stem-bark of $S$. birrea was minced, powdered and macerated in 31 distilled water for $48 \mathrm{~h}$ at room temperature. The water extracts were filtered through Whatman no. 3 filter paper and were concentrated under reduced pressure at $35^{\circ} \mathrm{C}$, yielding $160 \mathrm{~g}$ of a dark-brown (16\%) S. birrea extract (SBE).

For each series of experiments, the extract was weighed and dissolved in distilled water to obtain a $30 \mathrm{mg} / \mathrm{ml}$ stock solution.

\section{Animals and diabetes induction}

For in vivo studies, we used male Wistar rats weighing 200-250 g obtained from in-house breeding (Faculty of Science, University of Yaoundé I). The rats were kept and maintained in laboratory animal units under standard conditions of temperature and humidity with $12 \mathrm{~h}$ light: $12 \mathrm{~h}$ darkness cycle and free access to chow diet and water. Authorisation for the use of animals was obtained from the Institutional Animal Ethics Committee (N FW-IRB00001954).

Diabetes was induced by an i.p. injection of $110 \mathrm{mg} / \mathrm{kg}$ nicotinamide $15 \mathrm{~min}$ before an i.v. (penile vein) injection of $65 \mathrm{mg} / \mathrm{kg}$ streptozotocin (Sigma Chemicals) in 0.9\% sodium chloride solution. Non-diabetic control rats were injected with vehicle only.

Three days after diabetes induction, fasting blood glucose levels were determined using a glucometer (Boehringer Mannheim). Diabetes was allowed to develop and to stabilise over a period of 2 weeks before starting the treatments.

\section{Animal treatments and glucose tolerance test}

SBE at a dose of 150 or $300 \mathrm{mg} / \mathrm{kg}$ body weight, glibenclamide (Glib) at the dose of $10 \mathrm{mg} / \mathrm{kg}$ (positive control) and distilled water at $10 \mathrm{ml} / \mathrm{kg}$ (control group) were administered orally by gastric intubation, and each group consisted of six rats. Doses of SBE were selected based on previous animal studies (Ojewole 2003, Dimo et al. 2007) and use by traditional practitioners.

Chronic treatment was conducted by daily administration of the test compounds for 14 consecutive days with measurements of body weight and fasting glycaemia at the indicated times. At the end of the treatment period, rats were fasted overnight, killed, and plasma collected for analysis of insulin levels using a commercial kit (Mercodia, Uppsala, Sweden).

Acute effects were evaluated in fasted animals during a glucose tolerance test. Immediately after oral glucose $(5 \mathrm{~g} / \mathrm{kg})$ administration, test compounds were administered as described above, and glycaemia was recorded over a 5 -h period.

\section{Cell culture and treatments}

INS-1E cells (Merglen et al. 2004) were cultured in complete RPMI-1640 medium supplemented with 5\% heat-inactivated FCS, $1 \mathrm{mM}$ sodium pyruvate, $50 \mu \mathrm{M}$ 2-mercaptoethanol, $2 \mathrm{mM}$ glutamine, $10 \mathrm{mM}$ HEPES, $100 \mathrm{U} / \mathrm{ml}$ penicillin and $100 \mu \mathrm{g} / \mathrm{ml}$ streptomycin. Rat islets were isolated from adult male Wistar rats by collagenase perfusion (Carobbio et al. 2004) and cultured in complete RPMI-1640 medium.

INS-1E cells were seeded in 24-well plates and cultured in complete RPMI-1640 medium. After 3 days, the cells were incubated with the indicated concentrations of SBE (stock solution: $10 \mathrm{mg} / \mathrm{ml}$ dissolved in bidistilled water) for time periods as described.

Cell viability was assessed by trypan blue exclusion (Altman et al. 1993). Briefly, INS-1E cells that were seeded in 24-well plates for 3 days were cultured in the presence of $\operatorname{SBE}(0,10,20$ and $40 \mu \mathrm{g} / \mathrm{ml}$ ) for another $24-\mathrm{h}$ period. Then, the cells were dispersed with trypsin-EDTA before exposure to the membrane impermeant dye, trypan blue $(0 \cdot 4 \% \mathrm{w} / \mathrm{v})$. The presence of the dye within cells was visualised by light microscopy, and the numbers of stained cells versus unstained cells were determined. Moreover, apoptosis index was estimated using ethidium bromide staining assay (Ribble et al. 2005). In brief, following the 24-h period of exposure to increasing concentrations of SBE, INS-1E cells cultured in 24-well plates were stained with $40 \mu \mathrm{g} / \mathrm{ml}$ ethidium bromide, and fluorescence excited at $485 \mathrm{~nm}$ was recorded at $510 \mathrm{~nm}$ on a fluorimeter (Fluostar Optima, BMG Labtechnologies, Offenburg, Germany).

\section{Real-time quantitative RT-PCR}

Total RNA was extracted from treated and non-treated INS-1E cells using the RNeasy Mini Kit (Qiagen), and $2 \mu \mathrm{g}$ were converted into cDNA as previously described (Rubi et al. 2005). The real-time PCR measurement of cDNAs was performed using Power SYBR Green PCR Master Mix (Applied Biosystems, Rotkreuz, Switzerland) to measure duplex DNA formation and normalised to the expression of both transcription factor IIb (TFIIb) and $\alpha$-tubulin as control housekeeping genes. The primers used in the real-time RT-PCR are listed in Table 1. 
Table 1 Primers used for gene expression analysis

\begin{tabular}{|c|c|}
\hline & Primers sequence \\
\hline Glucokinase & $\begin{array}{l}5^{\prime} \text {-GTGGATGGCTCCGTGTACAAG-3' } \\
3^{\prime} \text {-GATTTCGCAGTTGGGTGTCA-5' }\end{array}$ \\
\hline Insulin & $\begin{array}{l}5^{\prime} \text {-TGCTCACCCGCGACCTT- } 3^{\prime} \\
3^{\prime} \text {-AAGTCAGGTCACCACGTATACTTG-5' }\end{array}$ \\
\hline Glut2 & $\begin{array}{l}5^{\prime} \text {-TCAGCCAGCCTGTGTATGCA- } 3^{\prime} \\
3^{\prime} \text {-ACAGAGACACGACGAACACCT-5' }\end{array}$ \\
\hline$P d x 1$ & $\begin{array}{l}\text { 5'-CCGCAGATTTACGGTGCATT-3' } \\
3^{\prime} \text {-CTTTCСCTCTACTTGCGCC-5' }\end{array}$ \\
\hline Tfam & $\begin{array}{l}5^{\prime} \text {-GGGAAGAGCAAATGGCTGAA-3' } \\
3^{\prime} \text {-AGAGTAGGCAGCGTCACATC-5' }\end{array}$ \\
\hline $\begin{array}{l}\text { Pyruvate } \\
\text { carboxylase }\end{array}$ & $\begin{array}{l}\text { 5'-GGCGAATTCCGATGGCAATCTCACCTCT- } \\
\text { GTTGGC-3' } \\
\text { 3'-GAAGCGGGGCAGCGGAGTTCGG-5' }^{\prime}\end{array}$ \\
\hline Cox1 & $\begin{array}{l}\text { 5'-AGCTGGCTTCGTCCACTGATT-3' } \\
3^{\prime} \text {-TACTGTGTACTCGTTTTCGGG-5' }\end{array}$ \\
\hline TFIIb & $\begin{array}{l}5^{\prime} \text {-TGTGTAGCTGCCATCTGCACTT-3' } \\
3^{\prime} \text {-GAACCACGAGGTGATCGTCGA-5' }\end{array}$ \\
\hline Tubulin & $\begin{array}{l}\text { 5'-TGCGGCAACCAGATTGG-3' } \\
3^{\prime} \text {-CGTGCCAGTGGGATCAATG-5' }\end{array}$ \\
\hline
\end{tabular}

\section{Insulin secretion assay}

The secretory responses were tested in INS-1E cells and rat islets. Briefly, after washing with glucose-free Krebs-Ringer bicarbonate Hepes buffer (KRBH, containing $135 \mathrm{NaCl}, 3 \cdot 6$ $\mathrm{KCl}, 10$ Hepes (pH 7.4), $5 \mathrm{NaHCO}_{3}, 0.5 \mathrm{NaH}_{2} \mathrm{PO}_{4}, 0.5$ $\mathrm{MgCl}_{2}$ and $1 \cdot 5 \mathrm{CaCl}_{2}$ in millimolar) with $0 \cdot 1 \% \mathrm{BSA}$ as insulin carrier, the cells were stimulated with the indicated glucose concentrations for $30 \mathrm{~min}$. Non-nutrient-stimulated insulin release was induced by the calcium-raising agent $\mathrm{KCl}$ (30 $\mathrm{mM}$ ) at basal $2.5 \mathrm{mM}$ glucose. The secretory response to mitochondrial substrates was tested at basal $2.5 \mathrm{mM}$ glucose using $2 \mathrm{mM}$ pyruvate, $10 \mathrm{mM} \boldsymbol{\alpha}$-ketoisocaproate and $5 \mathrm{mM}$ methyl succinate (Maechler et al. 1998a, 2006). Regarding the isolated pancreatic islets, these were washed, hand-picked and distributed into $3 \mathrm{ml}$ tubes in $\mathrm{KRBH}$ for static incubation over a 30-min period (Rubi et al. 2004). Incubations were stopped by putting plates (for INS-1E cells) or tubes (for islets) on ice, supernatants were collected for insulin secretion, and cellular insulin contents were determined from acid-ethanol extracts. Insulin secretion was measured by RIA using rat insulin as standard (Linco Research, St Charles, MO, USA).

\section{Cellular ATP and glucose oxidation}

Cellular ATP levels were monitored in a thermostated plate reader (Fluostar Optima) in INS-1E cells expressing the ATPsensitive bioluminescent probe luciferase in the presence of $100 \mu \mathrm{M}$ luciferin as described (Maechler et al. 1998b, Merglen et al. 2004). Changes in luminescence were monitored at basal $2.5 \mathrm{mM}$ glucose before stimulation during $20 \mathrm{~min}$ with $15 \mathrm{mM}$ glucose followed by the addition of the mitochondrial poison azide $(2 \mathrm{mM})$.
For glucose oxidation, INS-1E cells were incubated for $1 \mathrm{~h}$ with $\mathrm{KRBH}$ containing $15 \mathrm{mM}$ glucose traced with $0 \cdot 1 \mu \mathrm{Ci}$ [U- ${ }^{14} \mathrm{C}$ ]glucose (de Andrade et al. 2006). Formation of ${ }^{14} \mathrm{CO}_{2}$ was counted in a liquid scintillation counter (LKB Wallac 1217 Rackbeta counter, Turku, Finland). Glucose oxidation was normalised to cellular protein contents.

\section{Statistical analysis}

Unless otherwise indicated, data are the means \pm S.E.M. of at least three independent experiments. Differences between groups were assessed by the Student's $t$-test for single comparison and by one-way analysis followed by Bonferroni $t$-test for multiple comparisons. A $P$ value lower than $0 \cdot 05$ was considered as significant.

\section{Results}

\section{Treatment of diabetic rats with SBE}

At the end of the 2-week treatment period, i.e. 4 weeks after diabetes induction, diabetic control rats exhibited body weights $10 \%$ lower compared with non-diabetic animals $(P<0 \cdot 02)$ see Fig. 1A. Glib treatment maintained body weights comparable to non-diabetic rats, although SBE did not.

Fasting plasma glucose levels were dramatically increased 2 weeks after diabetes induction by streptozotocin, reaching values of $252 \pm 13 \mathrm{mg} / \mathrm{dl}$ in diabetic controls (Fig. 1B). After 7 days of daily treatment, both Glib and SBE, $300 \mathrm{mg} / \mathrm{kg}$, markedly reduced glycaemia to $121 \pm 8$ and $111 \pm 9 \mathrm{mg} / \mathrm{dl}$ respectively. SBE at the dose of $150 \mathrm{mg} / \mathrm{kg}$ was also efficient in correcting plasma glucose when compared with diabetic

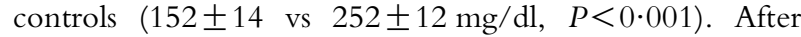
14 days of treatment, both Glib and SBE, $300 \mathrm{mg} / \mathrm{kg}$, groups exhibited glycaemia similar to non-diabetic rats. SBE at $150 \mathrm{mg} / \mathrm{kg}$ reduced plasma glucose levels to $133 \pm 9 \mathrm{mg} / \mathrm{dl}$, i.e. $-46 \%$ compared with diabetic controls $(P<0 \cdot 001)$.

At the end of the 2 -week treatment period, plasma insulin concentrations in diabetic controls were reduced to $8 \cdot 5 \pm 1 \cdot 3$ compared with $12.7 \pm 0.9 \mathrm{mU} / \mathrm{ml}$ in non-diabetic animals $(P<0 \cdot 001)$, see Fig. 2A. Both Glib and SBE, $300 \mathrm{mg} / \mathrm{kg}$, treatments restored insulin levels towards normal values $(P<0 \cdot 001$ versus diabetic control group). These data show efficient hypoglycaemic effects of chronic SBE treatment correlating with increased circulating insulin.

Acute effects of SBE were tested in vivo during an oral glucose tolerance test (Fig. 2B). Animals received simultaneously glucose load and treatment, both by gavage. Glib rapidly lowered plasma glucose close to non-diabetic levels $(163 \pm 7 \mathrm{mg} / \mathrm{dl}$ at $1 \mathrm{~h})$, an effect maintained over the $5-\mathrm{h}$ recording period. SBE at $300 \mathrm{mg} / \mathrm{kg}$ also reduced glycaemia towards non-diabetic levels, although the effects were slightly delayed compared with Glib. At $150 \mathrm{mg} / \mathrm{kg}$, SBE treatment significantly reduced plasma glucose levels at all time points, resulting in glycaemia of $168 \pm 12 \mathrm{mg} / \mathrm{d}$ at $5 \mathrm{~h}(-32 \%$ versus diabetic controls, $P<0 \cdot 001)$. 

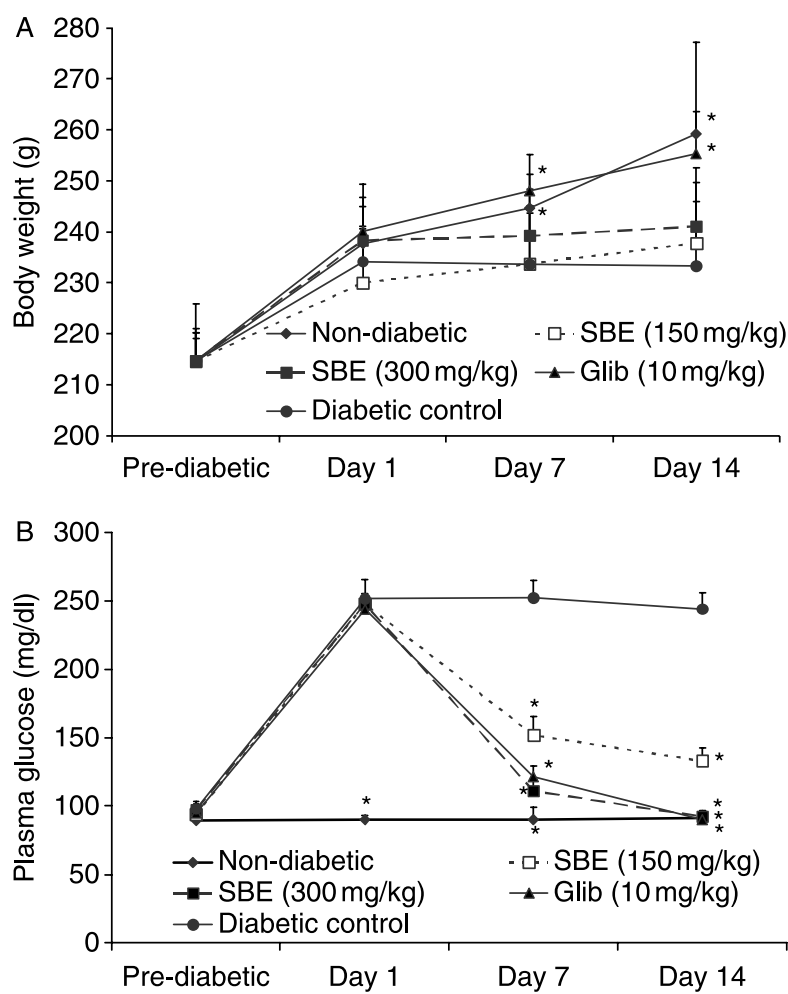

Figure 1 Effects of chronic SBE treatment on body weight and glycaemia in diabetic rats: diabetes was induced by streptozotocin injection (at time pre-diabetic), followed by a period of 2 weeks to stabilise the diabetic state before initiation of treatments (day 1 ). Daily oral administration of water (non-diabetic and diabetic control), of SBE (150 and $300 \mathrm{mg} / \mathrm{kg}$ ) and of glibenclamide $(10 \mathrm{mg} / \mathrm{kg}$, Glib) was continued for 14 days. Body weights (A) and fasting glycaemia (B) were recorded. ${ }^{*} P<0 \cdot 05$ versus diabetic control, $n=6$.

\section{SBE treatment and INS-1E insulin-secreting cell preservation}

In a previous study, SBE did not exhibit toxic effects in Chang liver cells exposed for $48 \mathrm{~h}$ to $12.5 \mu \mathrm{g} / \mathrm{ml}$ extract (van de Venter et al. 2008). In order to determine the safety threshold in insulin-secreting cells, we increased SBE concentrations up to $50 \mu \mathrm{g} / \mathrm{ml}$ over a $24-\mathrm{h}$ incubation period. Trypan blue assay was performed on INS-1E cells following the 24-h culture period in the presence of increasing concentrations of SBE (Fig. 3A). This revealed that concentrations up to $10 \mu \mathrm{g} / \mathrm{ml}$ SBE did not induce toxic effects. Using ethidium bromide staining assay, we measured the apoptosis index showing significant cell death at $50 \mu \mathrm{g} / \mathrm{ml} \mathrm{SBE}$ (Fig. 3B). According to these dose-responses, the concentration $5 \mu \mathrm{g} / \mathrm{ml}$ below the safety threshold was selected for the rest of the study.

Next, expression patterns of genes playing a key role in pancreatic $\beta$-cells were analysed following a 24-h culture period with $5 \mu \mathrm{g} / \mathrm{ml}$ SBE (Fig. 3C). In particular, we measured expression of metabolic genes (glucokinase $(G c k)$ and Glut2 (Slc2a2)), of mitochondrial function (pyruvate carboxylase $(P c x)$ and COX1 (Ptgs1)), of insulin and of TFs relevant for $\beta$-cell function ( $P d x 1$ and Tfam). Expression of the tested genes was not affected by SBE treatment, showing preserved differentiation of INS-1E cells upon SBE exposure.

\section{Effect of SBE on insulin secretion}

Acute effects of SBE on insulin secretion were tested in INS$1 \mathrm{E}$ cells cultured in 24-well plates (Fig. 4A). Sub-confluent INS-1E cells were exposed to $5 \mu \mathrm{g} / \mathrm{ml} \mathrm{SBE}$ for $1 \mathrm{~h}$ and then assayed for insulin secretion over a 30-min incubation period. In control cells, $15 \mathrm{mM}$ glucose stimulated insulin release $3 \cdot 0$-fold over basal release at $2.5 \mathrm{mM}$ glucose, in accordance with previous reports (Merglen et al. 2004). Acute SBE treatment did not modify basal release or glucose-stimulated insulin secretion.

Next, a time course of SBE exposure $(5 \mu \mathrm{g} / \mathrm{ml})$ was conducted over a $12-\mathrm{h}$ culture period terminated by glucoseinduced insulin secretion assays (Fig. 4B). Insulin release stimulated by $15 \mathrm{mM}$ glucose was potentiated in SBE-treated cells by $166 \%(P<0 \cdot 05)$ after $12 \mathrm{~h}$ compared with nontreated stimulated controls. Insulin release at $2.5 \mathrm{mM}$ glucose was not modified by SBE treatment.
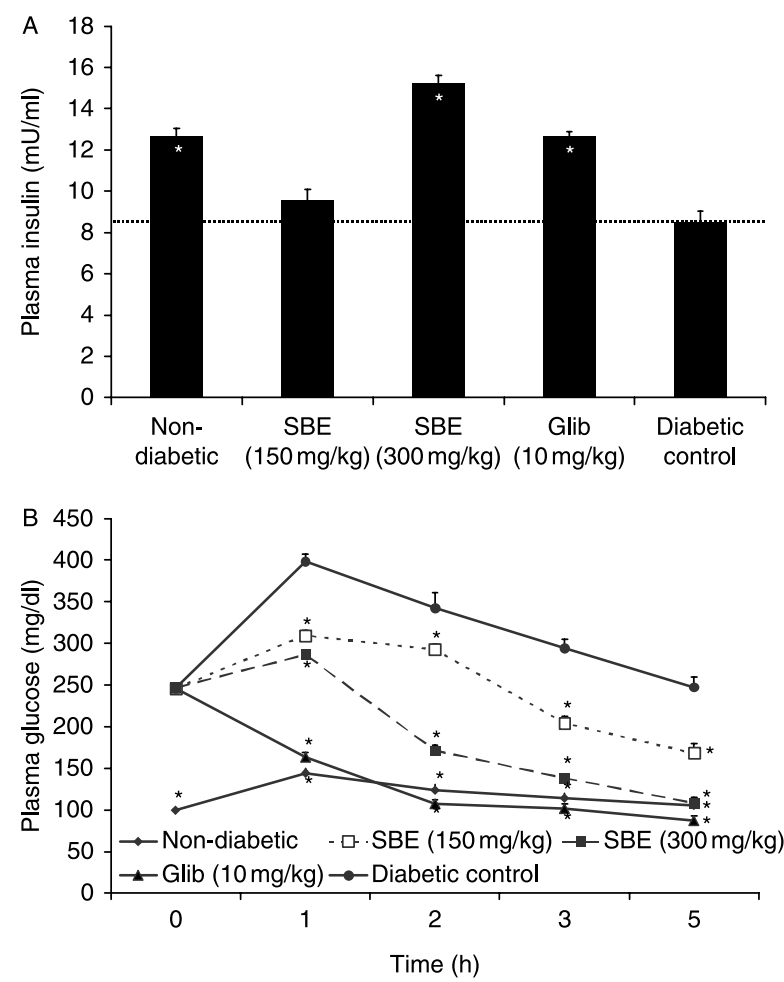

Figure 2 Effects of SBE treatment on insulin levels and glucose tolerance test in diabetic rats: diabetes was induced by streptozotocin injection followed by a period of 2 weeks to stabilise the diabetic state. (A) After 14 days of indicated daily treatments, fasted rats were killed, and plasma insulin levels were determined. (B) Fasted untreated rats with stabilised diabetes received one single acute treatment immediately after oral glucose load and glycaemia were monitored over 5 h. ${ }^{*} P<0 \cdot 05$ versus diabetic control, $n=6$. 

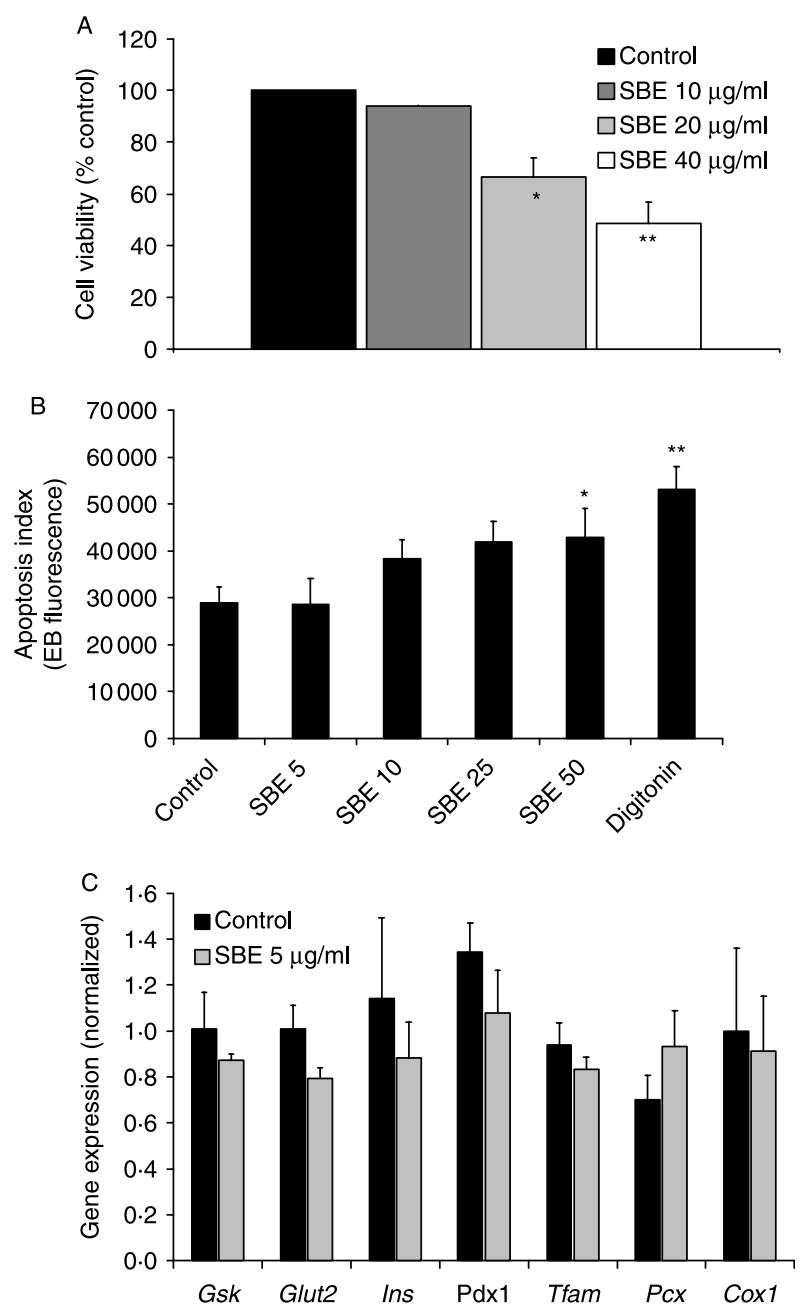

Figure 3 Effects of SBE treatment and INS-1E cell preservation: INS-1E cells were cultured to sub-confluency before treatment for $24 \mathrm{~h}$ with the indicated concentrations of SBE (in $\mu \mathrm{g} / \mathrm{ml}$ ). At the end of the 24-h treatment period, the cells were analysed for: (A) cell viability using trypan blue dye exclusion assay; (B) apoptosis index using ethidium bromide (EB) staining assay and digitonin $(30 \mu \mathrm{M})$ as positive control; (C) expression of selected genes (Gsk, glucokinase; Ins, insulin; PCX, pyruvate carboxylase). ${ }^{*} P<0 \cdot 05,{ }^{* *} P<0 \cdot 0005$ versus control, $n=3$.

Insulin secretion evoked by nutrient and non-nutrient secretagogues was then compared between control and $5 \mu \mathrm{g} / \mathrm{ml} \mathrm{SBE-treated} \mathrm{cells} \mathrm{following} \mathrm{a} \mathrm{24-h} \mathrm{culture} \mathrm{period}$ (Fig. 5A). Stimulatory glucose $(15 \mathrm{mM})$ induced a $3 \cdot 3$-fold response in controls and a 6.4-fold response in SBE-treated cells, corresponding to a $146 \%$ potentiation at high glucose $(P<0 \cdot 05)$. Non-nutrient-induced insulin release was evoked by depolarising concentrations of $\mathrm{KCl}(30 \mathrm{mM})$ in order to raise cytosolic calcium levels. Such metabolism-independent secretory response was not modified by SBE exposure (Fig. 5A). Insulin secretion was also tested by stimulating INS-1E cells with mitochondrial substrates (Fig. 5B).
In control cells, both $2 \mathrm{mM}$ pyruvate and $5 \mathrm{mM}$ methyl succinate significantly raised insulin secretion compared with basal release (4.5-fold, $P<0 \cdot 001 ; 1 \cdot 8$-fold, $P<0 \cdot 01$ respectively). On the contrary, $\alpha$-ketoisocaproate did not stimulate insulin release, tested at both $5 \mathrm{mM}$ (not shown) and $10 \mathrm{mM}$ (Fig. 5B). SBE-treated INS-1E cells exhibited similar responses to pyruvate and methyl succinate compared with control cells. However, $10 \mathrm{mM} \boldsymbol{\alpha}$-ketoisocaproate evoked a $1 \cdot 9$-fold secretory response $(P<0 \cdot 005)$, corresponding to a $50 \%$ increase compared with corresponding non-treated control $(P<0 \cdot 05)$. Insulin contents were not changed in INS-1E cells after $24 \mathrm{~h}$ of culture in the presence of $5 \mu \mathrm{g} / \mathrm{ml}$ SBE compared with controls $(1828 \pm 309$ vs 1942 $\pm 268 \mathrm{ng} /$ well respectively, $n=12$ ).

Primary $\beta$-cells were used to validate further the effects of SBE on insulin-secreting cells. Isolated pancreatic rat islets were cultured in the presence of SBE $(5 \mu \mathrm{g} / \mathrm{ml})$ for $24 \mathrm{~h}$ prior to measurements of glucose-stimulated insulin secretion (Fig. 5C). Basal insulin release at $2 \cdot 8 \mathrm{mM}$ glucose was not
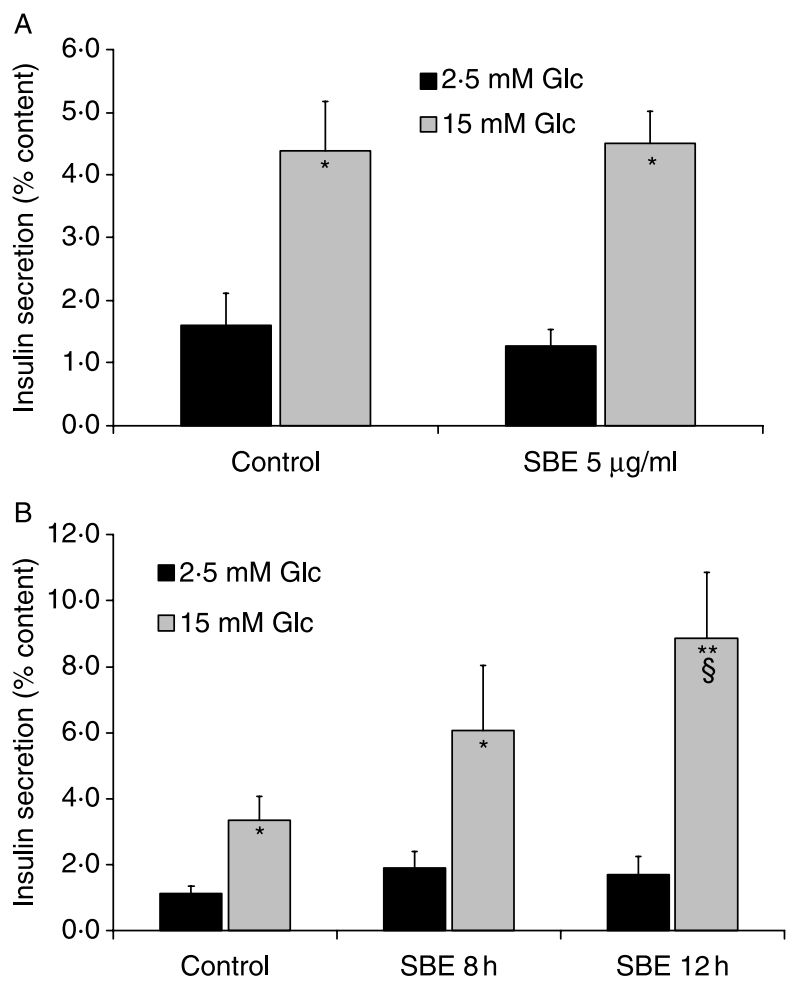

Figure 4 Time-course effects of SBE treatment on insulin secretion in INS-1E cells: INS-1E cells were cultured to sub-confluency before treatment with $5 \mu \mathrm{g} / \mathrm{ml}$ SBE for the indicated time periods. Then, insulin secretion was measured over a $30-\mathrm{min}$ incubation period at basal $2.5 \mathrm{mM}$ and stimulatory $15 \mathrm{mM}$ glucose (Glc) concentrations. (A) INS-1E cells were exposed to SBE for $1 \mathrm{~h}$ before insulin secretion assay $(n=4)$. (B) Prior to measurements of glucose-stimulated insulin secretion, INS-1E cells were cultured for 8 and $12 \mathrm{~h}$ with SBE or without the extract (control); $n=3 .{ }^{*} P<0 \cdot 05,{ }^{* *} P<0 \cdot 005$ versus basal $2.5 \mathrm{mM} \mathrm{Glc} ;{ }^{\S} P<0.05$ versus control $15 \mathrm{mM} \mathrm{Glc}$. 

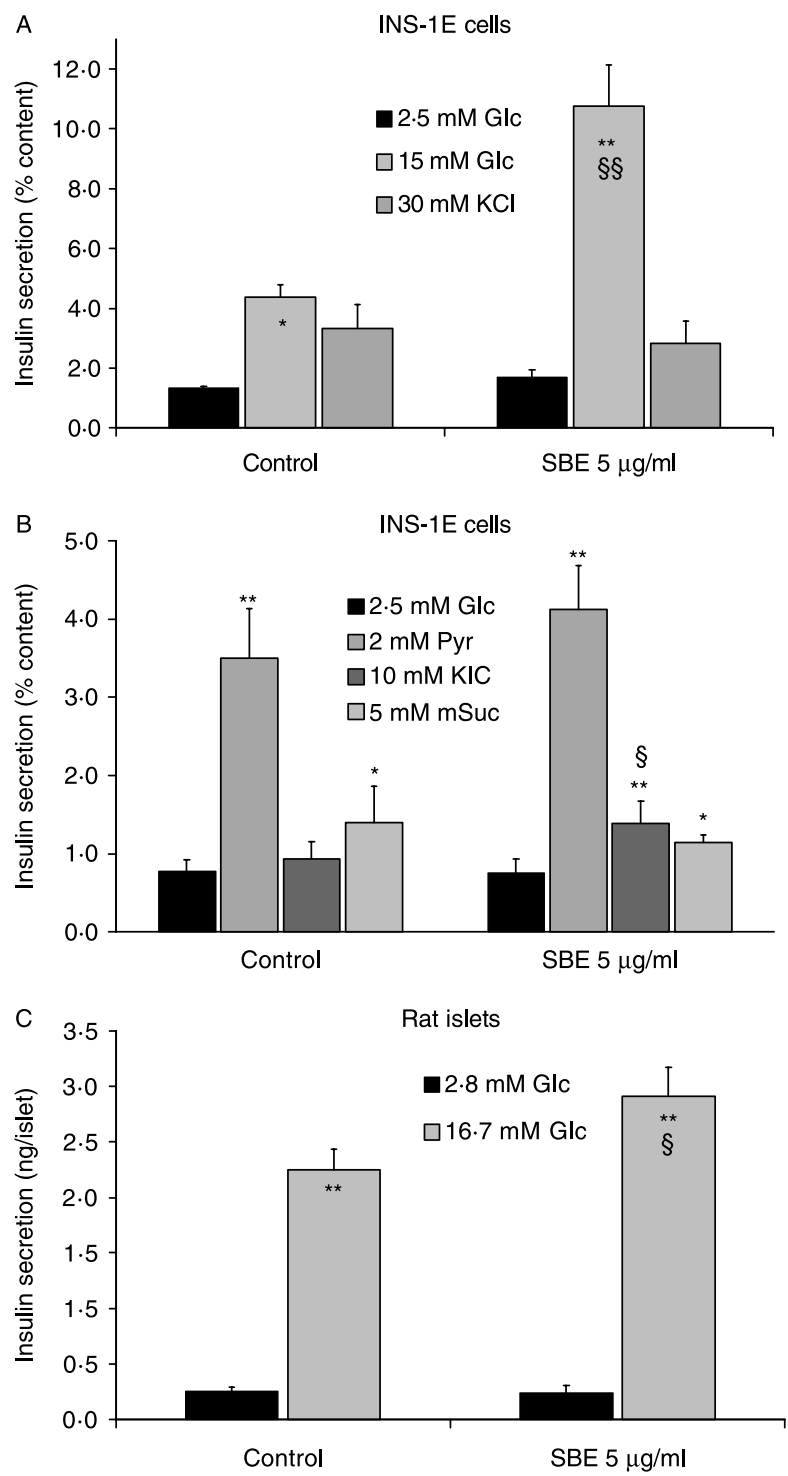

Figure 5 Effects of SBE treatment on the secretory responses of INS-1E cells and rat islets: sub-confluent INS-1E cells and isolated rat islets were cultured for $24 \mathrm{~h}$ with $5 \mu \mathrm{g} / \mathrm{ml}$ SBE before secretion assay. (A) INS-1E cells were incubated for $30 \mathrm{~min}$ at basal $2.5 \mathrm{mM}$ and stimulatory $15 \mathrm{mM}$ glucose (Glc) concentrations. Non-nutrient insulin release was tested at $30 \mathrm{mM} \mathrm{KCl}$ in the presence of basal $2.5 \mathrm{mM}$ glucose. (B) The secretory response to mitochondrial substrates was tested by 30-min incubation of INS-1E cells with $2 \mathrm{mM}$ pyruvate (Pyr), $10 \mathrm{mM} \alpha$-ketoisocaproate (KIC) and $5 \mathrm{mM}$ methyl succinate (mSuc). (C) Pancreatic islets were incubated for $30 \mathrm{~min}$ at basal $2.8 \mathrm{mM}$ and stimulatory $16.7 \mathrm{mM}$ glucose (Glc) concentrations. ${ }^{*} P<0 \cdot 05,{ }^{* *} P<0 \cdot 01$ versus basal Glc; ${ }^{\circledR} P<0 \cdot 05$, ${ }^{\$ \&} P<0 \cdot 001$ versus control stimulatory Glc, $n=3$.

affected by SBE exposure. Stimulatory glucose concentration $(16.7 \mathrm{mM})$ induced an $8 \cdot 8$-fold secretory response in control islets. SBE-treated islets exhibited a $12 \cdot 2$-fold glucose response, potentiating glucose-stimulated insulin secretion by $30 \%(P<0 \cdot 02)$ compared with controls.
Effect of SBE on ATP generation and glucose metabolism

Insulin secretion results pointed to metabolic effects following chronic SBE treatment. Accordingly, glucose-induced ATP generation and glucose oxidation were measured in INS-1E cells following a 24-h exposure to $5 \mu \mathrm{g} / \mathrm{ml} \mathrm{SBE}$.

Cellular ATP levels were monitored in INS-1E cells expressing luciferase (Fig. 6A). Control cells kept at $2.5 \mathrm{mM}$ glucose showed stable basal ATP levels. Raising glucose to $15 \mathrm{mM}$ induced sustained elevation of cellular ATP, which was abruptly disrupted after addition of the mitochondrial poison azide. In SBE-treated cells, glucose-stimulated ATP generation was markedly increased compared with controls, before similar azide-induced drop.

Finally, glucose metabolism was assessed by measurements of ${ }^{14} \mathrm{C}$-glucose oxidation to ${ }^{14} \mathrm{CO}_{2}$, reflecting the coupling of glycolytic rate to mitochondrial activity (Casimir et al. 2009). In SBE-treated INS-1E cells, glucose oxidation was increased by $49 \%(P<0 \cdot 05)$ compared with control cells. These data show enhanced glucose metabolism following chronic treatment with SBE.
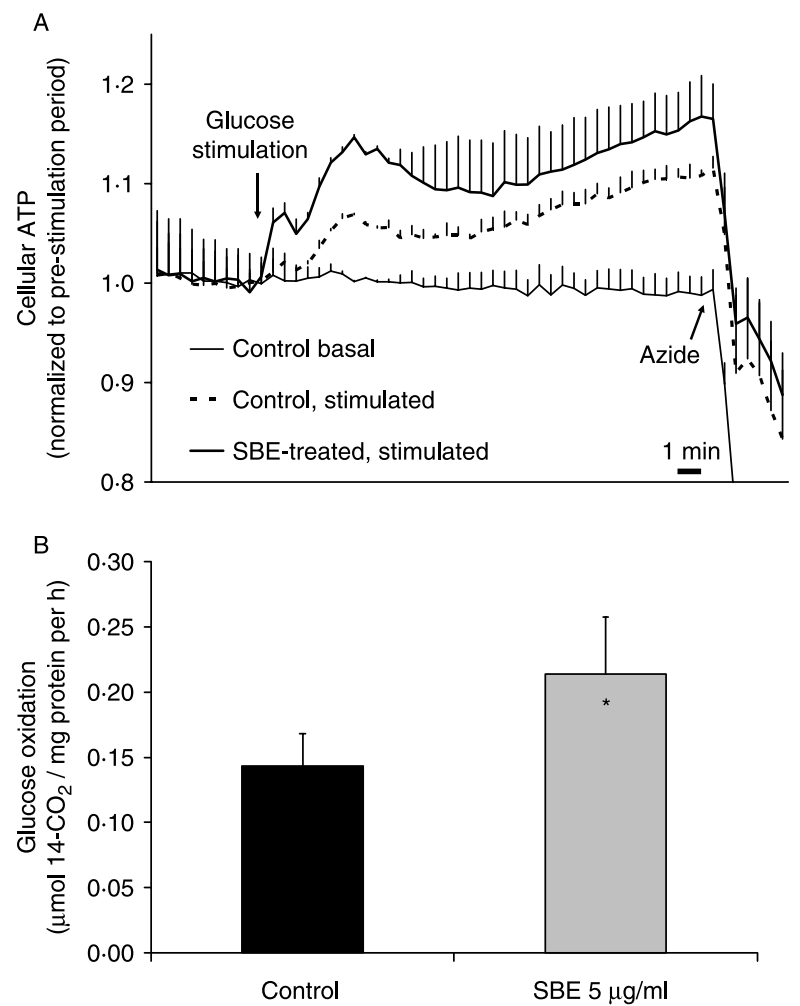

Figure 6 Effects of SBE on ATP generation and glucose metabolism: INS-1E cells were cultured to sub-confluency before treatment with $5 \mu \mathrm{g} / \mathrm{ml}$ SBE for $24 \mathrm{~h}$. (A) Cellular ATP, assessed by bioluminescence, was monitored in transduced cells expressing luciferase. Cells were stimulated with $15 \mathrm{mM}$ glucose (glucose stimulation), and $20 \mathrm{~min}$ later $2 \mathrm{mM}$ azide were added as an inhibitor of the respiratory chain. (B) Glucose oxidation to ${ }^{14} \mathrm{CO}_{2}$ was measured in INS-1E cells over a 1-h stimulation period with $15 \mathrm{mM}$ $\left[\cup-{ }^{14}\right.$ C]glucose. ${ }^{*} P<0 \cdot 05$ versus control, $n=3$. 


\section{Discussion}

SBE is widely used as traditional remedy against diabetes in Africa (Dieye et al. 2008). However, very little is known about the mechanisms of action conferring its hypoglycaemic effects. Here, we showed that glycaemia of diabetic rats was efficiently corrected by SBE treatment over a 2 -week period. $\mathrm{SBE}$ at a dose of $300 \mathrm{mg} / \mathrm{kg}$ exhibited an efficiency that was similar to that of Glib, and SBE at a dose of $150 \mathrm{mg} / \mathrm{kg}$ significantly lowered blood glucose after 1 week of treatment. Plasma insulin levels were increased by SBE treatment in vivo, indicating an action on pancreatic $\beta$-cells. Accordingly, we then investigated putative direct effects of SBE on $\beta$-cells.

Noteworthy, $150 \mathrm{mg} / \mathrm{kg}$ SBE efficiently reduced glycaemia although plasma insulin levels were similar to diabetic controls. This suggests that tissues other than pancreatic $\beta$-cells also contributed to the lowering of blood glucose. Indeed, SBE treatment was shown previously to increase hepatic glycogen storage to similar extent than metformin (Gondwe et al. 2008). Such liver-specific effects could possibly explain the blood glucose lowering effect observed in rats as soon as $1 \mathrm{~h}$ after the first administration of SBE. Among other molecules, SBE contains epicatechin-3-galloyl ester (Galvez Peralta et al. 1992) that is also present in green tea and is shown to improve glucose tolerance in diabetic mice and human subjects (Tsuneki et al. 2004). In the present study, acute treatment of insulin-secreting cells with SBE did not modify the secretory response of insulin-producing cells. Therefore, pancreatic $\beta$-cells are not likely to contribute to very early hypoglycaemic effects of SBE.

When tested in vitro on insulin-secreting cells, SBE exhibited strong potentiation of the secretory response at stimulatory glucose concentrations following a 24-h exposure period. This effect was observed both in insulinoma INS-1E cells and in primary pancreatic islets. Importantly, SBE did not stimulate insulin release at basal glucose, a property that prevented undesired hypoglycaemia in vivo. Toxicity assays and gene expression analysis showed the absence of cytotoxicity at effective concentrations as well as preserved differentiation of the insulin-secreting cells.

At the cellular level, the mechanism of action of SBE was associated with enhanced glucose metabolism. Indeed, SBE treatment increased both glucose oxidation and ATP generation upon glucose stimulation. Because these effects pointed to mitochondria as putative target of SBE action, expression of associated genes as well as secretory responses to mitochondrial substrates was tested. Corresponding results did support mitochondrial specificity; with the exception of $\alpha$-ketoisocaproate-induced insulin release in SBE-treated INS-1E cells. Therefore, data suggest that SBE promoted overall metabolic pathway of glucose metabolism leading to ATP formation.

In conclusion, this study provides the first evidence for direct action of SBE on pancreatic $\beta$-cells, enhancing glucose-stimulated insulin secretion. This correlated with hypoglycaemic effects in diabetic rats associated with restored levels of plasma insulin. Further investigations should identify the active molecules present in SBE. Clinical data with large cohorts of patients are also missing and should challenge $S$. birrea as an effective tool for the management of diabetes. These studies should be conducted to identify low-cost medications accessible for the increasing populations of diabetic patients in sub-Saharan regions (Gill et al. 2009).

\section{Declaration of interest}

The authors declare that there is no conflict of interest that could have prejudiced the impartiality of the research reported.

\section{Funding}

This work was supported by Swiss Government Scholarships programme (to IMN), the State of Geneva, the Swiss National Science Foundation (to PM) and the Third World Academy of Sciences through grant No. 06-020/RG/BIO/AF/AC-UNESCO FR: 3240144852.

\section{Acknowledgements}

The authors thank Gaelle Chaffard and Clarissa Bartley (Geneva) for expert technical assistance, Ning Li and Thierry Brun (Geneva) for helpful discussions and Paul Désiré Dzeufiet (Yaoundé) for advices regarding in vivo experiments. This study was part of the Geneva Programme for Metabolic Disorders.

\section{References}

Altman SA, Randers L \& Rao G 1993 Comparison of trypan blue dye exclusion and fluorometric assays for mammalian cell viability determinations. Biotechnology Progress 9 671-674.

de Andrade PB, Rubi B, Frigerio F, van den Ouweland JM, Maassen JA \& Maechler P 2006 Diabetes-associated mitochondrial DNA mutation A3243G impairs cellular metabolic pathways necessary for beta cell function. Diabetologia 49 1816-1826.

Ashcroft FM 2006 K(ATP) channels and insulin secretion: a key role in health and disease. Biochemical Society Transactions 34 243-246.

Carobbio S, Ishihara H, Fernandez-Pascual S, Bartley C, Martin-Del-Rio R \& Maechler P 2004 Insulin secretion profiles are modified by overexpression of glutamate dehydrogenase in pancreatic islets. Diabetologia 47 266-276.

Casimir M, Rubi B, Frigerio F, Chaffard G \& Maechler P 2009 Silencing of the mitochondrial NADH shuttle component aspartate-glutamate carrier AGC1/Aralar1 in INS-1E cells and rat islets. Biochemical Journal 424 459-466.

Dieye AM, Sarr A, Diop SN, Ndiaye M, Sy GY, Diarra M, Rajraji Gaffary I, Ndiaye Sy A \& Faye B 2008 Medicinal plants and the treatment of diabetes in Senegal: survey with patients. Fundamental \& Clinical Pharmacology 22 211-216.

Dimo T, Rakotonirina SV, Tan PV, Azay J, Dongo E, Kamtchouing P \& Cros G 2007 Effect of Sclerocarya birrea (Anacardiaceae) stem bark methylene chloride/methanol extract on streptozotocin-diabetic rats. Journal of Ethnopharmacology 110 434-438.

Eliasson L, Abdulkader F, Braun M, Galvanovskis J, Hoppa MB \& Rorsman P 2008 Novel aspects of the molecular mechanisms controlling insulin secretion. Journal of Physiology 586 3313-3324. 
Galvez Peralta J, Zarzuelo A, Busson R, Cobbaert C \& de Witte P 1992 (-)-Epicatechin-3-galloyl ester: a secretagogue compound from the bark of Sclerocarya birrea. Planta Medica 58 174-175.

Gill GV, Mbanya JC, Ramaiya KL \& Tesfaye S 2009 A sub-Saharan African perspective of diabetes. Diabetologia 52 8-16.

Gondwe M, Kamadyaapa DR, Tufts M, Chuturgoon AA \& Musabayane CT 2008 Sclerocarya birrea [(A. Rich.) Hochst.] [Anacardiaceae] stem-bark ethanolic extract (SBE) modulates blood glucose, glomerular filtration rate (GFR) and mean arterial blood pressure (MAP) of STZ-induced diabetic rats. Phytomedicine 15 699-709.

Iynedjian PB 2009 Molecular physiology of mammalian glucokinase. Cellular and Molecular Life Sciences 66 27-42.

Maechler P, Kennedy ED, Wang H \& Wollheim CB 1998a Desensitization of mitochondrial $\mathrm{Ca}^{2+}$ and insulin secretion responses in the beta cell. Journal of Biological Chemistry 273 20770-20778.

Maechler P, Wang H \& Wollheim CB 1998b Continuous monitoring of ATP levels in living insulin secreting cells expressing cytosolic firefly luciferase. FEBS Letters 422 328-332.

Maechler P, Carobbio S \& Rubi B 2006 In beta-cells, mitochondria integrate and generate metabolic signals controlling insulin secretion. International Journal of Biochemistry \& Cell Biology 38 696-709.

Merglen A, Theander S, Rubi B, Chaffard G, Wollheim CB \& Maechler P 2004 Glucose sensitivity and metabolism-secretion coupling studied during two-year continuous culture in INS-1E insulinoma cells. Endocrinology 145 667-678.

Ojewole JA 2003 Hypoglycemic effect of Sclerocarya birrea [(A. Rich.) Hochst.] [Anacardiaceae] stem-bark aqueous extract in rats. Phytomedicine 10 675-681.
Ribble D, Goldstein NB, Norris DA \& Shellman YG 2005 A simple technique for quantifying apoptosis in 96-well plates. BMC Biotechnology $\mathbf{5} 12$.

Rubi B, del Arco A, Bartley C, Satrustegui J \& Maechler P 2004 The malateaspartate NADH shuttle member Aralar1 determines glucose metabolic fate, mitochondrial activity, and insulin secretion in beta cells. Journal of Biological Chemistry 279 55659-55666.

Rubi B, Ljubicic S, Pournourmohammadi S, Carobbio S, Armanet M, Bartley C \& Maechler P 2005 Dopamine D2-like receptors are expressed in pancreatic beta cells and mediate inhibition of insulin secretion. Journal of Biological Chemistry 280 36824-36832.

Tsuneki H, Ishizuka M, Terasawa M, Wu JB, Sasaoka T \& Kimura I 2004 Effect of green tea on blood glucose levels and serum proteomic patterns in diabetic $(\mathrm{db} / \mathrm{db})$ mice and on glucose metabolism in healthy humans. BMC Pharmacology 418.

van de Venter M, Roux S, Bungu LC, Louw J, Crouch NR, Grace OM, Maharaj V, Pillay P, Sewnarian P, Bhagwandin N et al. 2008 Antidiabetic screening and scoring of 11 plants traditionally used in South Africa. Journal of Ethnopharmacology 119 81-86.

\section{Received in final form 7 December 2009}

Accepted 8 January 2010

Made available online as an Accepted Preprint 8 January 2010 